\title{
Study of Trace Elements in Patients of Hypothyroidism with Special Reference to Zinc and Copper
}

\author{
Manisha Arora ${ }^{1 *}$, Roshan Kumar Mahat ${ }^{1,2}$, Sudeep Kumar ${ }^{1}$, Imran Mustafa ${ }^{1}$ and Sumesh Prasad Sah ${ }^{1}$ \\ ${ }^{1}$ Department of Biochemistry, Muzaffarnagar Medical College, India \\ ${ }^{2}$ Department of Biochemistry, Gajra Raja Medical College, India
}

Received: June 22, 2018; Published: July 05, 2018

*Corresponding author: Manisha Arora, Professor and Head, Department of Biochemistry, Muzaffarnagar Medical College, Muzaffarnagar (U.P), India

\begin{abstract}
Background: Hypothyroidism is a clinical entity resulting from a deficiency of thyroid hormones or, more rarely, from their impaired activity at the tissue level. Several mineral and trace elements are essential for normal thyroid hormone metabolism and co-existing deficiencies of these elements can impair thyroid function. The present study was conducted with the aim to find out the concentrations of zinc and copper in hypothyroidism and to determine the possible correlations between trace elements and thyroid hormones.

Material and Methods: Our study included 40 patients with hypothyroidism and 40 normal control subjects. In all the subjects, T3, T4, and TSH were measured by ELISA whereas trace elements zinc and copper were measured colorimetrically.

Results: Both zinc and copper were significantly reduced in patients of hypothyroidism as compared to controls $(57.05 \pm 7.54 \mu \mathrm{g} / \mathrm{dl}$ vs. $98.02 \pm 7.77 \mu \mathrm{g} / \mathrm{dl}, \mathrm{p}<0.001$ and $73.86 \pm 6.22 \mu \mathrm{g} / \mathrm{dl}$ vs. $114.97 \pm 18.18 \mu \mathrm{g} / \mathrm{dl}, \mathrm{p}<0.001$, respectively). Zinc was significantly and positively correlated with T3 $(r=0.326 ; \mathrm{p}<0.05)$ in hypothyroidism patients but there was no significant correlation of zinc with rest of the hormones i.e, T4 $(r=0.078 ; p>0.05)$ and TSH $(r=-0.026 ; p>0.05)$ levels. With regard to copper, we did not find any significant correlation of copper with T3 $(\mathrm{r}=0.076 ; \mathrm{p}>0.05)$, T4 $(\mathrm{r}=0.171 ; \mathrm{p}>0.05)$ and TSH $(\mathrm{r}=0.167 ; \mathrm{p}>0.05)$.
\end{abstract}

Conclusion: In conclusion, hypothyroid patients had significantly decreased concentration of zinc and copper. Hence, diet rich in trace elements, viz. zinc and copper should be supplied to patients of hypothyroidism in order to maintain normal thyroid hormone function.

Keywords: Hypothyroidism; Trace Elements, Zinc, Copper

Abbreviations: LDL: Low Density Lipoprotein

\section{Introduction}

Endocrine disorders are common among Indian population, out of which thyroid disorders represents an important subset of these endocrine disorders [1]. Thyroid diseases are primarily conditions that affect the amount of thyroid hormones being produced [2]. Hypothyroidism is characterized by a broad clinical spectrum ranging from an overt state of myxedema, end-organ effects and multisystem failure to an asymptomatic or subclinical condition with normal levels of thyroxine and triiodothyronine and mildly elevated levels of serum thyrotropin $[3,4]$. The prevalence of hypothyroidism in the developed world is about 4-5\% [5,6]. However, in India, Unnikrishnan et al. conducted a study in eight different cities and found a high prevalence of hypothyroidism (10.95\%), affecting approximately 1 in 10 adults in the population [7]. Hypothyroidism can lead to a number of complications in humans such as: a) Mental health issues such as depression and cause the slow functioning of the brain,

b) Heart problems because of increase in the level of lowdensity lipoprotein (LDL) cholesterol. Sometimes it causes heart failure and enlarges the heart,

c) In hypothyroidism, the low levels of thyroid hormone can alter the process of ovulation which leads to infertility in women [8].

In order to maintain optimal health of an individual, adequate supply of carbohydrates, proteins, lipids, macronutrients, micronutrients as well as trace elements are needed [9]. Although the levels of trace elements are low in human body, they play an essential role in a number of biological processes through their action as activators or inhibitors of enzymatic reactions, by competing 
with other elements and proteins for binding sites, by influencing the permeability of cell membranes, or through other mechanisms. Trace elements are known to influence hormones at levels of action, including hormone secretion and activity and binding to target tissue. Conversely, hormones influence trace metals metabolism at several levels of action, including excretion and transport of trace elements [10]. Some of the important elements include selenium, iron, and manganese, copper (Cu), and zinc ( $\mathrm{Zn}$ ). Deficiency, lack, and an increase of trace elements can cause irrepa $\neg$ rable damages [11]. $\mathrm{Zn}$ is an essential trace element which is important for thyroid function and normal thyroid homeostasis. Its roles are complex and may include effects on both the synthesis and mode of action of the hormones [12].

Basically, $\mathrm{Zn}$ is required for the proper function of the "enzyme 1,5'- deiodinase," the enzyme catalyzes" the conversion of biologically thyroxine (T4) to its active form triiodothyronine (T3) and decreases the metabolic rate [13]. In addition to this, thyroid hormone binding transcription factor, which are essential for modulation of gene expression, also contain zinc bound to cysteine residues [14]. Copper, the third most abundant mineral in the human body, plays an important role in thyroid metabolism, especially in hormone production and absorption. Copper stimulates the production of the thyroxine hormone $\mathrm{T} 4$ and prevents over absorption of T4 in the blood cells by controlling the body's calcium levels. Apart from this, copper is also required for the synthesis of phospholipids, which are required for the stimulation of thyroid stimulating hormone [15]. The study regarding the role of trace elements in hypothyroidism is not well documented in the literature; hence,we have planned this study with the aim to find out the concentrations of zinc and copper in hypothyroidism and to determine the possible correlations between trace elements and thyroid hormones.

\section{Materials and Methods \\ Study design and Subjects}

The present case-control study was carried out in the Department of Biochemistry, Muzaffarnagar Medical College, Muzaffarnagar after getting approval from Institutional Ethical Committee. 40 diagnosed patients with hypothyroidism aged between 20 to 60 years of either sex were taken as cases and 40 normal healthy age and gender-matched individuals were taken as controls. The patients with hypothyroidism were diagnosed on the basis of clinical examinations and hormones levels (T3, T4, and TSH) by a physician. The controls were taken from in and around of Muzaffarnagar Medical College, Muzaffarnagar. Patients of hepatic disease, renal disease, malabsorption syndrome, those who are suffering from any other endocrinal disorders e.g. diabetes, those who are on nutritional and antioxidants supplements, smokers, tobacco chewers and subjects not willing to give consent were excluded from the present study. Written informed consent was taken from cases and controls after a full explanation of the study.

\section{Biochemical Measurements}

About $5 \mathrm{~mL}$ of venous blood sample was collected under all aseptic precautions from cases and controls and transferred to the sterile plane test tube. The blood was allowed to clot and centrifuged at $5000 \mathrm{rpm}$ for 5 minutes. Sera were separated and stored at $-20^{\circ} \mathrm{C}$ until analysis. T3, T4, and TSH were measured by using commercially available ELISA kit (Bene Sphera Avantor Inc, India). Serum zinc and copper were determined by colorimetric method.

\section{Statistical Analysis}

Statistical analysis and interpretation of data were done by Statistical Package for Social Science version 20 (IBM, SPSS statistics 20, Armonk, NY, USA). The data were checked for normality by using Shapiro-Wilk test. The statistical differences between cases and controls were determined by student independent sample t-test and Mann-Whitney U test for normally distributed data and skewed data, respectively. Chi-square test is used for categorical data. Pearson's correlation analysis was done to find a probable correlation between variables. p-value less than 0.05 were considered significant.

\section{Results}

The total number of subjects included in the present study was 80 , out of which 40 were patients with hypothyroidism and 40 were normal healthy control individuals. Table 1 shows the clinical characteristics of the subjects included in the study. The average age of hypothyroidism patients and control subjects were $36.93 \pm 8.59$ years and $34.38 \pm 7.69$ years respectively. By statistical analysis, we found no significant differences between these two groups with regard to age, indicating that cases and controls were age matched. There was no significant difference in sex distribution between cases and controls. Both zinc and copper were significantly reduced in patients of hypothyroidism as compared to controls $(57.05 \pm 7.54 \mu \mathrm{g} / \mathrm{dl} v s .98 .02 \pm 7.77 \mu \mathrm{g} / \mathrm{dl}, p<0.001$ and $73.86 \pm 6.22$ $\mu \mathrm{g} / \mathrm{dl} v s .114 .97 \pm 18.18 \mu \mathrm{g} / \mathrm{dl}, p<0.001$, respectively). Table 2 shows Pearson's correlation analysis between variables in hypothyroidism patients. Zinc was significantly and positively correlated with T3 $(\mathrm{r}=0.326 ; p<0.05)$ in hypothyroidism patients but there was no significant correlation of zinc with rest of the hormones i.e. T4 $(\mathrm{r}=0.078 ; p>0.05)$ and TSH $(\mathrm{r}=-0.026 ; p>0.05)$ levels. With regard to copper, we did not find any significant correlation of copper with T3 ( $\mathrm{r}=0.076 ; p>0.05)$, T4 ( $\mathrm{r}=0.171 ; p>0.05)$ and TSH ( $\mathrm{r}=0.167$; $p>0.05)$. Figure 1 shows a comparison of zinc and copper between controls and hypothyroidism patients.

Table 1: Shows the clinical characteristics of the subjects included in the study.

\begin{tabular}{|c|c|c|}
\hline Variables & Control subjects $(\mathrm{n}=40)$ & Hypothyroid subjects $(\mathrm{n}=40)$ \\
\hline Age $($ years $)$ & $34.38 \pm 7.69$ & $36.93 \pm 8.59$ NS \\
\hline Sex $(\mathrm{M} / \mathrm{F})$ & $16 / 24$ & $13 / 27 \mathrm{NS}$ \\
\hline $\mathrm{T} 3(\mathrm{ng} / \mathrm{ml})$ & $1.15 \pm 0.25$ & $0.44 \pm 0.04^{* *}$ \\
\hline $\mathrm{T} 4(\mu \mathrm{g} / \mathrm{dl})$ & $7.10 \pm 1.16$ & $3.43 \pm 0.52^{* *}$ \\
\hline
\end{tabular}




\begin{tabular}{|c|c|c|}
\hline TSH $(\mu \mathrm{IU} / \mathrm{dl})$ & $3.86 \pm 0.86$ & $42.07 \pm 17.36^{* *}$ \\
\hline $\mathrm{Zn}(\mu \mathrm{g} / \mathrm{dl})$ & $98.02 \pm 7.77$ & $57.05 \pm 7.54^{* *}$ \\
\hline $\mathrm{Cu}(\mu \mathrm{g} / \mathrm{dl})$ & $114.97 \pm 18.18$ & $73.86 \pm 6.22^{* *}$ \\
\hline
\end{tabular}

Results are shown as mean \pm SD; T3: Triiodothyronine; T4: Thyroxine; TSH: Thyroid stimulating hormone; Zn: Zinc; Cu: Copper; NSNon significant; **Significant at $\mathrm{p}<0.001$

Table 2: Shows Pearson's correlation analysis between variables in hypothyroidism patients.

\begin{tabular}{|c|c|c|c|c|c|}
\hline Parameters & T3 & T4 & TSH & Zn & $0.326^{*}$ \\
\hline T3 & 1 & $0.545^{* *}$ & $-0.492^{* *}$ & 0.078 & 0.076 \\
\hline T4 & $0.545^{* *}$ & 1 & $-0.420^{* *}$ & -0.026 & 0.171 \\
\hline TSH & $-0.492^{* *}$ & $-0.420^{* *}$ & 1 & 1 & -0.167 \\
\hline Zn & $0.326^{*}$ & 0.078 & -0.026 & -0.008 & 1 \\
\hline
\end{tabular}

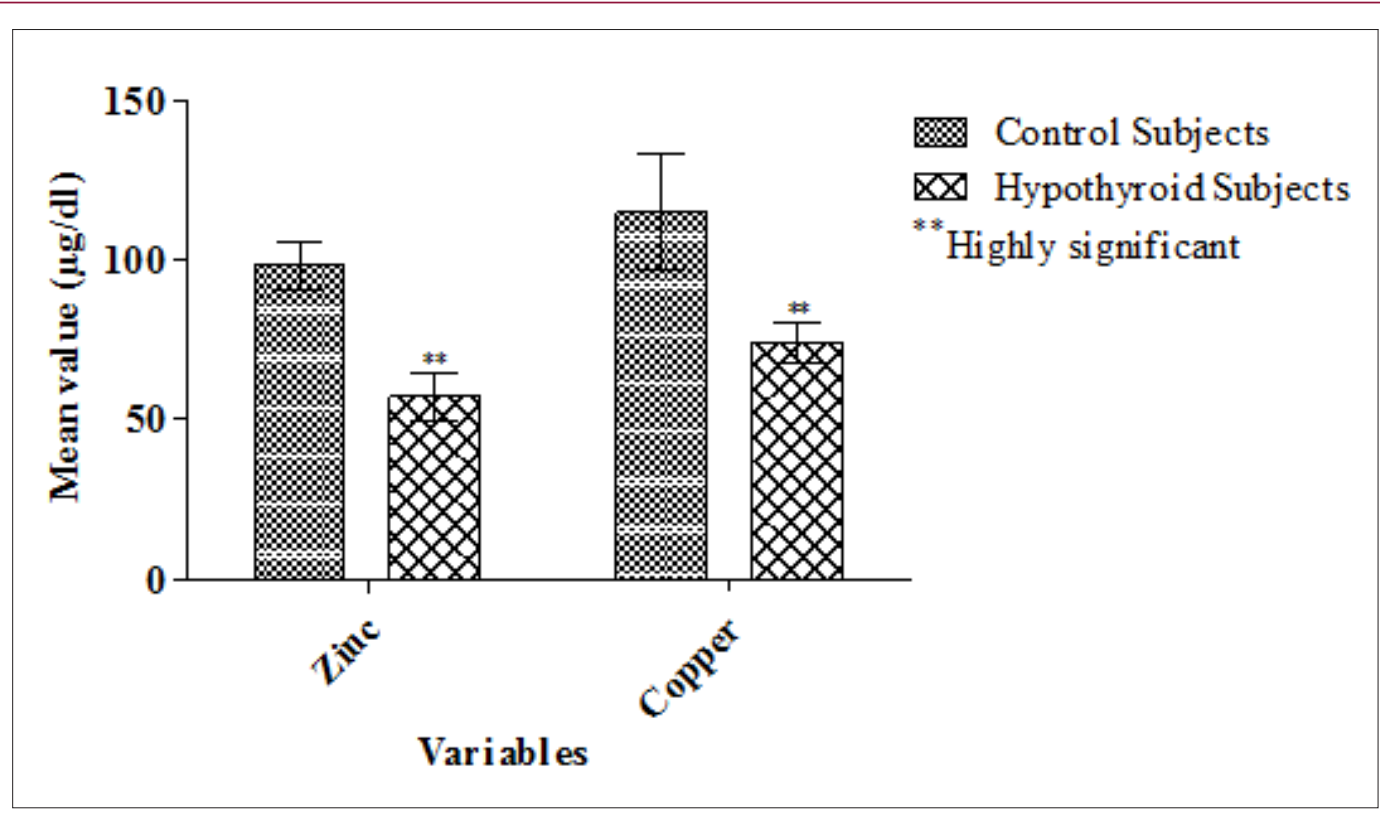

Figure 1: Comparison of Zinc and Copper between controls and hypothyroidism patients.

\section{Discussion}

Hypothyroidism is a clinical entity resulting from a deficiency of thyroid hormones or, more rarely, from their impaired activity at the tissue level. In hypothyroidism, the basal metabolic rate is decreased, as are other processes dependent upon thyroid hormones [16]. In the present study, we in ᄀvestigated serum $\mathrm{Zn}$ and $\mathrm{Cu}$ concentrations in partients of hypothyroidism and found a possible correlation of these trace elements with thyroid hormones. Several mineral and trace elements are essential for normal thyroid hormone metabolism and co-existing deficiencies of these elements can impair thyroid function [17]. Zinc affects thyroid hormone at several levels e.g. zinc deficiency inhibits TRH synthesis [18] and depresses TSH, T4, and T3 [19]. It is also necessary for extrathyroidal conversion of T4 to T3 [20] and it plays role in $\mathrm{T} 3$ binding to the nuclear receptor as well as the binding of the receptor to DNA [21]. Alternation in thyroid function has been reported in zinc-deficient status [22], on the other hand, hypothyroidism induced zinc deficiency in humans, as well as zinc deficiency causes hypothyroidism [23].
In our study, we found significantly decreased level of zinc in patients of hypothyroidism as compared to control subjects, which is in line with the findings of Mohammed et al. [15], Baloch et al. [24], Al-Juboori et al. [25], Ali et al. [26], Jinger et al. [27], Rashid et al. [28]. The possible mechanism for the decreased level of zinc in hypothyroidism patients is that gastrointestinal absorption of zinc is severely impaired in these patients[29]. Another explanation, according to the study done by Bellisola, is due to the significant influence of TSH in the variations of concentration of iodine, selenium, and zinc in normal and altered human thyroid tissues [30]. In addition to this, the tubular excretion of $\mathrm{Zn}$ also leads to low levels of plasma zinc [31]. Copper is an essential element, acts as a cofactor for tyrosinase which is required for the biosynthesis of tyrosine; a protein component of thyroglobulin needed for the synthesis of the thyroid hormones [32]. In the present study, we revealed the significantly decreased level of copper in patients with hypothyroidism as compared to controls which is consistent with the previous studies $[27,28]$.

However, most of the authors in their studies found no significant difference in copper level between hypothyroidism patients and 
control subjects [15,24-26]. As there is an alteration in the level of copper in hypothyroidism patients, correct levels are needed to prevent thyroid problems and can be used in the treatment of thyroid disease. We found a significant and positive correlation of zinc with T3 level, but there was no significant correlation of zinc with rest of the hormones i.e. T4 and TSH levels. However, we did not found any significant correlation of copper with T3, T4, and TSH in hypothyroidism patients. These results are same as reported by Rashid et al. [28]. The significant positive correlation of zinc with T3 may be because of decreased activity of hepatic type I 5-deiodinase by $67 \%$ during Zn deficiency [33]. Another possible reason for this might be the T3 receptor is thought to require zinc to adopt its biologically active conformation [34].

\section{Conclusion}

In conclusion, hypothyroid patients had significantly decreased levels of zinc and copper, which indicates abnormal metabolism of zinc and copper in hypothyroidism and may exaggerate the complications of hypothyroidism. Hence, diet rich in trace elements, viz. zinc and copper should be supplied to patients with hypothyroidism in order to maintain normal thyroid hormone function. However, studies with a large number of hypothyroid patients are needed in order to get more precise results.

\section{References}

1. Vanderpump MP, Tunbridge WM, French JM, Appleton D, Bates D, et al. (1995) The incidence of thyroid disorders in the community: A twentyyear follow-up of the whickham survey. Clin Endocrinol 43(1): 55-68.

2. Rabeh NM, El Ghandour HA (2016) Effect of Iron, Zinc, Vitamin E and Vitamin C supplementation on thyroid hormones in rats with hypothyroidism. Int J Nutr Food Sci 5(3): 201-210.

3. Cooper DS (2001) Clinical practice. Subclinical hypothyroidism. N Engl J Med 345(4): 260-265.

4. Roberts CG, Ladenson PW(2004) Hypothyroidism. Lancet 363(9411): 793-803.

5. Hollowell JG, Staehling NW, Flanders WD, Hannon WH, Gunter EW, et al. (2002) Serum TSH, T (4), and thyroid antibodies in the United States population (1988 to 1994): National Health and Nutrition Examination Survey (NHANES III). J Clin Endocrinol Metab 87(2): 489-499.

6. Hoogendoorn EH, Hermus AR, de Vegt F, Ross HA, Verbeek AL, et al. (2006) Thyroid function and prevalence of anti-thyroperoxidase antibodies in a population with borderline sufficient iodine intake: Influences of age and sex. Clin Chem 52(1): 104-111.

7. Unnikrishnan AG, Kalra S, Sahay RK, Bantwal G, John M, et al. (2013) Prevalence of hypothyroidism in adults: An epidemiological study in eight cities of India. Indian J Endocrinol Metab 17(4): 647-652.

8. Khanam S (2018) Impact of zinc on thyroid metabolism. J Diabetes MetabDisord Control 5(1): 00134.

9. Solomons N (1993) Trace Elements. In 'Clinical Nutrition: Parenteral Nutrition' (2 ${ }^{\text {nd }}$ Edn.). Philadelphia pp. 150-183.

10. Henkin RI (1976) Trace Elements in Endocrinology. Med Clin North America 60(4): 779-797.

11. Siddiqui K, Bawazeer N, Joy SS (2014) Variation in macro and trace elements in progression of type 2 diabetes. Scientific World Journal 461591.

12. Ahmed RO, Abdrabo AA (2016) Levels of serum zinc and manganese among Sudanese patients with thyroid dysfunction. J Med Biol Sci Res 2(2): 33-35.
13. Ezzat Aziz M, Habil NY, Kareem A, Diab S (2016) Effectiveness of zinc supplementation in regulating serum hormonal and inflammatory status in hypothyroidism patients. Med J Babylon 13(2): 347-353.

14. Civitareale D, Saiardi A, Falasca P (1994) Purification and characterization of thyroid transcription factor 2. Biochem 304(3): 981-985.

15. Mohammed HIY, Idrees OF, Ismail AM, Ahmed SA (2015) Evaluation of copper and zinc among hyper and hypothyroidism patients. European Acad Res 3(5): 5422-5434.

16. Laurberg P, Andersen S, Bulow P, Carle A (2005) Hypothyroidism in the elderly: pathophysiology, diagnosis and treatment. Drugs Aging 22(1): 23-38.

17.Zimmermann MB, Kohrle J (2002) The impact of iron and selenium deficiency on iodine and thyroid metabolism: Biochemistry and relevance to public health. Thyroid 12(10): 867-878.

18. Morley JE, Gordon J, Hershman JM (1980) Zinc deficiency, chronic starvation, and hypothalamic-pituitary-thyroid function. Am J Clin Nutr 33(8): 1767-1770.

19. Pekary AE, Bhasin S, Smith V, Sugawara M, Swerdloff RS, et al. (1987) Thyroid hormone modulation of thyrotrophin-releasing hormone (TRH) and TRH-Gly levels in the male rat reproductive system. J Endocrinol 114(2): 271-277.

20. Pekary AE, Lukaski HC, Mena I, Hershman JM (1991) Processing of TRH precursor peptides in rat brain and pituitary is zinc dependent. Peptides 12(5): 1025-1032.

21. Anselmet A, Bismuth J, Torresani J (1983) Triiodothyronine nuclear receptor. Role of histones and DNA in hormone binding. BiochimBiophys Acta 739(3): 291-300.

22. Olivier JW, Sachan DS, Su P, Applehans FM (1987) Effects of zinc deficiency on thyroid function. Drug Nutr Interact 5(2): 113-124.

23. Pimenta WP, Brandäo Neto J, Curi PR (1992) Renal handling of zinc in insulin dependent diabetes mellitus patients. Trace Elem Med 9: 34-37.

24. Baloch S, Memon AR, Hayat AS, Masood N (2013) Evaluation of serum copper and zinc in hypothyroidism patients. ARPN J Sci Technol 3(3): 316-318.

25. Al-Juboori IA, Al Rawi R, A Hakeim HK (2009) Estimation of serum copper, manganese, Selenium, and zinc in hypothyroidism patients. IUFS J Biol 68(2): 121-126.

26. Ali EA, Kadhem H, Hussein A (2008) Estimation of serum copper, manganese, selenium and zinc in hypothyroid patients. J Fac Med Baghdad 50(2): 255-260.

27. Jinger SK, Choudhary M, Vyas RK (2015) Comparative study of trace elements in healthy controls and hypothyroidism patients in western Rajasthan. Global J Res Anal 4(2): 157-159.

28. Rashid NF, Abed BA, Abas TA (2010) Relationship between some trace elements, lipid profile and hypothyroidism. AJPS 8(2): 127-138.

29. Yoshida K, Kiso Y, Watanabe T, Kaise K, Kaise N, et al. (1990) Erythrocyte zinc in hyperthyroidism: reflection of integrated thyroid hormone levels over the previous few months. Metabolism 39(2): 182-186.

30. Bellisola G, Bratter P, Cinque G, Francia G, Galassini S, et al. (1998) The TSH-dependent variation of the essential elements iodine, selenium and zinc within human thyroid tissues. J Trace Elem Med Biol 12(3): 177182.

31. Baltaci AK, Mogulkoc R, Belviranli M (2013) Serum levels of calcium, selenium, magnesium, phosphorus, chromium, copper and iron-their relation to zinc in rats with induced hypothyroidism. Acta Clinical Croatica 52(2): 151-156.

32. Adedapo KS, Sonuga AA, Afolabi AO, Amosu A (2014) Interaction of some selected trace elements with thyroid hormones in patients with goiter in Ibadan, Nigeria. J Sci Res Rep 3(22): 2875-2883. 
33. Kralik A, Eder K, Kirchgessner M (1996) Influence of zinc and selenium deficiency on parameters relating to thyroid hormone metabolism. Horm Metab Res 28(5): 223-226.

(c) (i) This work is licensed under Creative Submission Link: https://biomedres.us/submit-manuscript.php
34. Freak HC, Goveni KE, Guda K, Huang C, Zinn SA (2001) Action and interactions of thyroid hormones and zinc status in growing rats. J Nutr 131(4): 1135-1141.

Assets of Publishing with us
RESEARCHES $\quad \begin{aligned} & \text { Global archiving of articles } \\ & \text { - Immediate, unrestricted online access }\end{aligned}$

